\title{
UNIVERSITY OF TOKYO RADIOCARBON MEASUREMENTS I
}

\section{JUN SATO,* TOMOKO SATO, ${ }^{* *}$ and HISASHI SUZUKI $\dagger$}

Carbon Dating Laboratory, University of Tokyo, Japan

The University of Tokyo Carbon Dating Laboratory was established to meet the requirements for dating materials from various fields of science at the university. Installation and testing of the apparatus as well as routine assays have been carried out with counsel of Dr. Nobufusa Saito, Professor of Chemistry, and Dr. Yozo Nogami, Professor of Physics, the University of Tokyo. Management of the laboratory is undertaken by the Carbon Dating Committee of he University of Tokyo. The laboratory has actually been working for a year. This article reports the radiocarbon age measurements made from September 1966 to July 1967, together with a brief description of the measuring system.

Our laboratory uses a proportional gas counter made by M.B.L.E., Belgium (Type RNR 054) with an actual volume of $1 \mathrm{~L}$. A ring guard counter of $1.2 \mathrm{~L}$ surrounding the central counter is arranged in anticoincidence. The central counter and the guard counter are separated by a thin plastic screen (styloflex metalized on both sides, $60 \mu$ thick) to reduce background counts attributed to gamma-ray components in the natural background. The counter is shielded with $5-10 \mathrm{~cm}$ thick iron and lead. Special precaution was taken to avoid spurious counts, and noise from electronic circuits were completely eliminated. Background is reduced to $1.5-2.0 \mathrm{cpm}$ and the counting rate of the oxalic acid standard from NBS is $12-13 \mathrm{cpm}$ at the normal counting pressures. Counting gas is introduced into the counter as purified acetylene at a pressure of $1 \mathrm{~atm}$ at room temperature $\left(23^{\circ} \mathrm{C}\right)$.

Prior to sample preparation, rootlets and other contaminating foreign materials in charcoal and wood samples are removed by handpicking. Wood samples are then charred. Samples are boiled in $1 \% \mathrm{NaOH}$ solution for a few hours to solubilize lignin and humic acid. Samples are then boiled in dil. $\mathrm{HCl}$ solution to remove carbonates. $\mathrm{CO}_{2}$ is produced by combustion in the oxygen stream.

Marble as the dead carbon material and corals are broken into small pieces, and contaminating materials, if any, are handpicked. Crushed samples are pretreated with dil. $\mathrm{HCl}$ solution to dissolve the outer layer. Then they are treated with $6 \mathrm{M} \mathrm{HCl}$ solution to release $\mathrm{CO}_{2}$.

The NBS oxalic acid standard, modern carbon standard material, is treated either by direct combustion in oxygen or oxidlation by $\mathrm{KMnO}_{4}$ in $\mathrm{H}_{2} \mathrm{SO}_{4}$ solution.

Samples are converted into acetylene by the method of Suess (Suess, 1954) using $\mathrm{CO}_{2} \rightarrow \mathrm{CaCO}_{3} \rightarrow \mathrm{SrCO}_{3} \rightarrow \mathrm{SrC}_{2} \rightarrow \mathrm{C}_{2} \mathrm{H}_{2}$ reaction. The chem-

* Department of Chemistry, Faculty of Science, the Universtiy of Tokyo.

**Department of Anthropology, Faculty of Science, the University of Tokyo.

†Chairman, the Carbon Dating Committee of the University of Tokyo.

Hailing address: c/o Department of Anthropology, Faculty of Science, University of Tokyo, Bunkyo-ku, Tokyo, Japan. 
ical yield in the conversion of $\mathrm{CO}_{2} \rightarrow \mathrm{C}_{2} \mathrm{H}_{2}$ is about $70 \%$. When a sample is limited, it is diluted with dead carbon in carbonate form at the $\mathrm{CaCO}_{3}$ stage, for the chemical yield of purified $\mathrm{CaCO}_{3} \rightarrow \mathrm{SrCO}_{3}$ reaction is almost $100 \%$ in this system.

Counting gas is purified with a small amount of active charcoal cooled at dry ice-ethanol temperature. Its purity is qualitatively checked by mass spectrometry.

The plateau curve was checked by the internal modern standard sample. The plateau curve of each counting gas is checked by an external ${ }^{137} \mathrm{Cs}$ radiation source. It ranges about $600 \mathrm{~V}$ and the slope is about $2 \% / 100 \mathrm{~V}$. The range and slope are almost the same as those of the former. The plateau curve is measured for each sample at the beginning and end of counting. It verifies absence of variation in counting gas. The activitiy of each sample is counted for $24 \mathrm{hrs}$ at least twice, several days apart, replacing the modern standard and background measurement in rotation.

Contemporary value for all dates is $95 \%$ of the activity of oxalic acid standard from the U.S. National Bureau of Standards, as recommended at the 1959 Groningen Radiocarbon Conference. The value of $5570 \pm 30 \mathrm{yr}$ is used as the half-life of $\mathrm{C}^{14}$. The results are expressed in years before 1950 , denoted by years B.P.

Ages reported here are the average values of dates which agree with each other within $2 \sigma$. The errors given include the standard deviation of the counting rate of unknown samples, of the NBS standard, and of the background.

\section{ACKNOWLEDGMENTS}

The authors thank Drs. Yuji Yokoyama, Kazuo Sato, Kasuke Takahashi, and Mr. Nobuyuki Saito for their efforts in developing this project. Special thanks go to Prof. Kunihiko Kigoshi, Gakushuin Univ., who made several suggestions on these measurements. Special thanks are also due Dr. Tatsuji Hamada, Institute of Physical and Chemical Research, who supplies us with water of low tritium content. We are indebted to Miss Yasuko Otomori for her cooperation and Miss Satoko Mikami for trping.

This project has been supported in part by a Grant in Aid for Fundamental Scientific Research from the Ministry of Education.

\section{SAMPLE DESCRIPTIONS}

I. GEOLOGIC SAMPLES

\section{Japan}

\section{Numa series}

Samples from Numa coral bed at Kōyatsu, Tateyama city, Chiba pref. (34 $57^{\prime} \mathrm{N}$ Lat, $139^{\circ} 50^{\prime} \mathrm{E}$ Long). The bed indicates postglacial climatic optimum. Coll. 1966 by Y. Hamada and subm. 1966 N. Katavama. Univ. of Tokyo. 
TK-7. Numa

Coral (Favia specieosa). Comment (N.K.): same sample measured by ${ }^{234} \mathrm{U}-{ }^{230} \mathrm{Th}$ method at Kanazawa Univ. with result $7100 \pm 300$ yr (personal commun.).

TK-8. Numa

$4700 \pm 500$

2750 B.C.

Coral (Stylocoemiella hanzawai). Comment (N.K.): same sample measured by ${ }^{23+} \mathrm{U}-{ }^{230} \mathrm{Th}$ method at Kanazawa Univ. with result 7400 $\pm 400 \mathrm{yr}$ (personal commun.).

TK-15. Satte

$4120 \pm 100$

2170 B.C.

Peat from borehole at natural levee formed by Furu-Tone River, depth 10.85 to $11.70 \mathrm{~m}$ (alt $11.0 \mathrm{~m})$, Satte, Saitama pref. $\left(36^{\circ} 03^{\prime} \mathrm{N}\right.$ Lat, $139^{\circ} 42^{\prime}$ E Long). Sample from black peaty bed on marine deposits overlain by fluvial deposits. Coll. 1964 by Y. Sakaguchi, Dept. of Geog., Univ. of Tokyo; subm. 1966 by S. Iwatsuka, Dept. of Geog., Unir. of Tokyo.

\section{TK-16. Shirane}

$13,900 \pm 200$

\section{1,950 в.c.}

Peat from borehole in alluvial plain, depth 112 to $125 \mathrm{~m}$ (alt $2 \mathrm{~m}$ ), Shrane, Niigata pref. (37 $46^{\prime} \mathrm{N}$ Lat, $139^{\circ} 01^{\prime} \mathrm{E}$ Long). Coll. 1962 by Y. Sakaguchi; subm. 1966 by S. Iwatsuka. Comment (S.I.) : stratigraphy indicates dated layer probably accumulated at middle of Würm Ice age.

\section{Asama Volcano series}

Sample from charred stems of wood destroyed by volcanic eruptions of Mt. Asama, Nagano pref. Coll. 1966 by I. Murai et al., Univ. of Tokro.

\section{TK-21. Amaike}

$\mathbf{8 7 0} \pm \mathbf{8 0}$

Charcoal from deposit on Oiwake pyroclastic flow at Amaike, Komoro city, on SW foot of Mt. Asama (30 $21^{\prime} \mathrm{N}$ Lat, $138^{\circ} 27.5^{\prime} \mathrm{E}$ Long). Subm. 1967 by N. Saito, Univ. of Tokyo. Flow is interpreted to have erupted in 1281 A.D., forming the most voluminous deposit among recent pyroclastic formations at Asama Volcano.

\section{TK-22a. Onioshidashi}

$433 \pm 70$

Check sample. Charcoal from deposits of Agatsuma pyroclastic flow at Onioshidashi (30 26.3' N Lat, $138^{\circ} 32.3^{\prime}$ E Long). Subm. by J. Sato. From inner part of wood stem charred by volcanic eruption in 1783 A.D. Comment (J.S.): this sample provides historical check of our radiocarbon dating method. Validity of age calculations for Japanese samples based on NBS oxalic acid standard can also be checked.

\section{TK-22b. Onioshidashi}

A.D. 1756

$$
194 \pm 60
$$

\footnotetext{
From bark of charred wood.
} 


\section{ARCHAEOLOGIC SAMPLES}

\section{A. Japan}

\section{TK-1. Minamihori}

$$
4970 \pm 80
$$

3020 B.c.

Charred timber from floor of dwelling pit No. 10 of Early Jomon period at Minamihori shell-mound, Minami-Yamadacho, Kita-ku, Yokohama city, Kanagawa pref. ( $35^{\circ} 32^{\prime} \mathrm{N}$ Lat, $139^{\circ} 37^{\prime} \mathrm{E}$ Long). Excavation 1955 by S. Wajima (1958), Research Institute for Natural Resources. Pottery is Moroiso A type. Coll. 1955 and subm. 1963 by N. Watanabe, Univ. of Tokyo. Comment (N.W.): date comparable to $5230 \pm 100$ (TK-3, this list), $5290 \pm 140$ (N-38, Riken II) and $5100 \pm 400$ (M-240, Michigan I) associated with same type pottery.

\section{TK-3. Kamo}

$$
5230 \pm 100
$$

Wood from peat formation which yielded dug-out canoe of Early Jomon period at Kamo, Toyota-mura, Awa-gun, Chiba pref. $\left(35^{\circ} 01^{\prime}\right.$ N Lat, $139^{\circ} 50^{\prime}$ E Long). Excavation Dec. 1948 by R. Fujita and N. Matsumoto, Keio Univ. (Matsumoto et al., 1952). Pottery is Moroiso A type. Coll. 1948 by J. Shimizu, Keio Univ.; subm. 1966 by N. Watanabe. Comment (N.W.): wood from same peat layer gave $5290 \pm 140$ (N-38, Riken II) and $5100 \pm 400$ (M-240, Michigan I). See also TK-1, this list.

\section{Tokoro Chashi series}

Charcoal from pit houses at Tokoro Chashi (fort), Tokoro-machi, Tokoro-gun, Hokkaido (44 $06^{\prime} \mathrm{N}$ Lat, $144^{\circ} 06^{\prime} \mathrm{E}$ Long). Excavation 1960 by K. Komai (1964), Dept. of Archaeology, Univ. of Tokyo. Pottery is of Okhotsk type. Coll. 1960 and subm. 1966 by K. Komai.

TK-2. Pit House No. 1

$1230 \pm 100$

Comment (K.K.): same sample gave $990 \pm 140$ (Gak-190, Gakushuin II).

TK-9. Pit House in Trench T

$1180 \pm 100$

\section{Gifu II site series}

Charcoal from pit house at Gifu II site, Tokoro-machi, Tokoro-gun, Hokkaido (44 $07^{\prime} \mathrm{N}^{\prime}$ Lat, $143^{\circ} 59^{\prime} \mathrm{E}$ Long). Excavation 1965 and 1966 by T. Mikami, Dept. of Archaeol. Univ. of Tokyo. Pottery is Satsumon type.

TK-4. Pit House No. 13

$$
1140 \pm 70
$$

Charcoal, coll. 1965 and subm. 1966 by T. Mikami.

Charcoal, coll. 1966 and subm. by T. Mikami. Comment (T.M.): dates are a little older than expected. 


\section{B. Peru}

\section{Chavín de Huantar series}

Chavín de Huantar, great ceremonial center, presumably of Formative period is on left bank of Mosna R., tributary of Marañón R., N highland of Peru $\left(9^{\circ} 25^{\prime} \mathrm{S}\right.$ Lat, $77^{\circ} 05^{\prime} \mathrm{W}$ Long). Coll. 1966 by Luis G. Lumbreras, San Marcos Univ.; subm. 1967 by S. Izumi, Univ of Tokyo.

\section{TK-18. Temple of Chavín}

Charcoal from Section RCA, Galeriá de las Ofrendas, associated with Classic Chavín style pottery. Comment (S.I.): dates of parallel phase at Kotosh sites, Kotosh Chavín, are $3150 \pm 150$ (Gak-263, unpublished) and $2820 \pm 120$ (N-65-2, Riken II).

TK-19. Mosna phase

$$
1820 \pm 80
$$

Charcoal from Section RC, 12A-B, Stratum 4, Mosna phase, last phase at site.

\section{TK-20. Huarás phase}

$$
1780 \pm 110
$$

Charcoal from Section RC, 9D, Stratum 7, Huarás phase.

Date lists:

\section{REFERENCES}

$\begin{array}{ll}\text { Gakushuin II } & \text { Kigoshi and Endo, 1963 } \\ \text { Michigan I } & \text { Crane, 1956 } \\ \text { Riken II } & \text { Yamasaki, Hamada, and Fujiyama, 1966 }\end{array}$

Crane, H. R., 1956, University of Michigan radiocarbon dates I: Science, r. 124, p. $664-672$.

Kigoshi, K. and Endo K., 1963, Gakushuin natural radiocarbon measurements II: Radiocarbon, v. 5, p. 109-117

Komai, K. (ed.), 1964: The archacological sites on the Okhotsk sea coast and the Shiretoko peninsula in Hokkaido, v. 2: Faculty of Letters, Univ of Tokyo, p. 1-193.

Matsumoto, N., Fujita, R., Shimizu, J., and Esaka, T., 1952, Kamo: a study of the Neolithic site and a Neolithic dugout canoe discovered at Kamo, Chiba prefecture, Japan: Publ. Hist. Dept., Fac. Letters, Keio Univ., Archacol. Ethnol. ser. 3., p. 1-138.

Suess, H E., 1954, Natural radiocarbon measurements by acetylene counting: Science, v. 120 , p. $5-7$.

Wajima, S., 1958, Minamihori shell-mound, a prehistoric village site: History of Yokohama city, issued by Yokohama Municipal Office, v. 1, p. 29-46.

Yamasaki, F., Hamada, T., and Fujiyama, C., 1966, Riken natural radiocarbon measurements II: Radiocarbon, v. 8, p. 324-339. 